\title{
Local Culinary Development Strategy in Improving the Tourist Attraction in Tedis Beach Kupang
}

\author{
Friend Zakharia \\ Hospitality Study Program, Tourism Department \\ Politeknik Negeri Kupang \\ Kupang, Indonesia \\ friend.zakharia@pnk.ac.id
}

\author{
Protasius Tiberius Jehane ${ }^{1}$, Fahri Adiputra Wely ${ }^{2}$ \\ ${ }^{1}$ Tourism Study Program, ${ }^{2}$ Hospitality Study Program \\ 1,2 Tourism Department \\ Kupang, Indonesia
}

\begin{abstract}
Tedis Beach is one of the special interest tourism attraction well-known in Kupang City especially for culinary, the diversity of local culinary that can be processed and served saves a potential in increasing the attractiveness of a tour on the Tedis Beach. The purpose of this study is to determine the potential of local culinary in Tedis Beach and to be able to find out local culinary development strategies that can increase the tourist attraction of the Tedis Beach. This research is descriptive using primary and secondary data. The method of data analysis is descriptive qualitative. In analysing the data are done by collecting primary data and secondary data. Data and information obtained through field research are then analysed. In analysing data, SWOT analysis used, SWOT analysis is an analysis of the external and internal environment. The results showed that there are a lot of local culinary potentials that can be developed as a tourist attraction on Tedis Beach. The results show that local culinary has its advantages, namely uniqueness that cannot be obtained in other regions plus a beautiful view. Even though local culinary entrepreneurs around Tedis Beach pay less attention to appearance, both food, outlet, and personal appearance. Incessant types of international cuisine that enter through the franchise around Tedis Beach can be used as momentum in further increasing the variety and distinctiveness of cuisine while maximizing tourist arrivals through Kupang both domestically and abroad.
\end{abstract}

Keywords—development strategy, local culinary

\section{INTRODUCTION}

Local culinary is a form of culture that has specific regional characteristics, a variety that reflects the natural potential of the area of each food, not only as a means to fulfil one's nutrition, food is also useful for maintaining human relationships, the identity symbol of a particular community and can also be sold and promoted to support tourism of an area. One of the cities in Indonesia that has a unique culinary variety is Kupang.

The variety of culinary delights in Kupang is based on existing food resources, especially Tedis Beach, which has plentiful fish resources, processed in traditional ways to produce various types of culinary delights that have their own taste.
Food tourism has been recognized as means of attraction, and tourist dining experience and tasting pleasure has been seen the most important factor [1]. People have interest and curiosity about locally grown food and locally produced food items, local taste. Exploring, tasting and experiencing local food is also a source of attraction for these people [2].

Beside the positive effects of local foods, the low quality in terms of hygiene, taste, presentation and service can negatively affect the health of tourist consequently disrupt the travel and can damage the reputation of the destination. The authenticity of the local foods and the quality of the service in their presentation is also one of the issues to be considered. The appearance, taste, aroma and smell of the dishes not only address the senses but also contribute to the perception of local difference [3].

Based on the description above, the writer is interested in explaining and further studying the strategy of developing culinary potentials in the city of Kupang that deserves to be developed both in terms of taste and appearance well packaged so that it can be well received by tourists. The author will research further about local culinary development strategies that can increase tourist attractions in Tedis Beach, Kupang.

\section{LITERATURE REVIEW}

\section{A. Development Strategy}

Strategy is a game plan to achieve it. Every business must design a strategy to achieve its objectives, which consists of a marketing strategy and a technology strategy as well as an appropriate sourcing strategy [4]. Strategy is a company with environmental challenges, designed to ensure that the main objectives of the company can be achieved through proper implementation by the organization [5].

Development can be interpreted as an effort to advance or improve something to be more than it is. Development can also be interpreted as a dynamic process using all available resources to achieve better welfare. This development can be in the form of physical form or the form of quality in the sense of quality. 
Strategy as the way an organization connects, responds, integrates and utilizes the surrounding environment. The strategy of a company or business organization will integrate with the mission, objectives and action plans so that when the strategy is well formulated, it will greatly assist the company in maximizing the use of its resources [6]. Thus, the company can get a place in a more strategic position compared to the position of other competitors. In connection with efforts to develop culinary NTT, the role of marketing is the most decisive. Determination of the right marketing strategy formulation will be able to provide maximum benefit in the business of eating and drinking.

\section{B. Culinary Tourism}

Culinary tourism is a journey in which food and the atmosphere of the area to be used as tourist attractions [7]. Tourism can be referred to as a gastronomy tour where tourists who come have a goal to pamper the stomach and get the experience of eating and cooking food [8]. That tourist attractions that serve food and drinks can be grouped into gastronomic attractions sourced from products, basic ingredients, recipes, seasonings, how to make, how to serve and how to taste food and drinks. Food tourism can be concluded as travel with the main purpose is food and drink and not only choose delicious food that is tasted. Besides tasting food and drinks, food tourism sees the value and experience of the food and drink itself [9].

\section{Local Culinary}

Local culinary or traditional food has cultural values, traditions, and beliefs that are rooted in local culture. Very influential on the food patterns of the tribes in Indonesia, including the selection of raw materials, eating patterns and traditions, eating habits and presentation methods. The traditional food of an area can be a reflection of the civilization and culture of an area which will be properly served by the local community [10].

Traditional food or local culinary is a type of food that is closely related to an area and passed down from generations as part of tradition. The local culinary specialties of the regions in Indonesia have been around for a long time and have survived until now, so they are valued as cultural heritage [11].

The attractiveness of a destination usually related to capacity of meeting tourist and expectations. For tourist evaluating destination attractiveness beside the climate. Accommodation, natural, historical and cultural richness, it also is one of the most important experiences is to try local food and beverages [12]. Local foods, food experiences and food tourism which are important element in terms of destination attractiveness, have been receiving more attention in recent years [13]. Accordingly, travelling to experience the destination specific foods are increasing rapidly and this is called food tourism.

Beside the positive effects of local foods, the low quality in terms of hygiene, taste, presentation and service can negatively affect the health of tourist consequently disrupt travel and can damage reputation of the destination. The authenticity of the local foods and the quality of the service presentation is also one of the issues to be considered. The appearance, taste, aroma and smell of the dishes not only address the senses but also contribute to the perception of local difference [14].

Almost all regions have special foods that can be categorized as tourist attractions, but this great potential has not been seriously worked on as a tourist asset. With this great potential, to elevate culinary as a tourism asset it is necessary to form food tourism activities (attractions and events) combined with local tourism attractions. So based on some of the descriptions above we can conclude that Tedis Beach is one of the tourist attractions that have the potential as one of the culinary attractions that must apply a development strategy so that it can be explained in the following framework of thought:

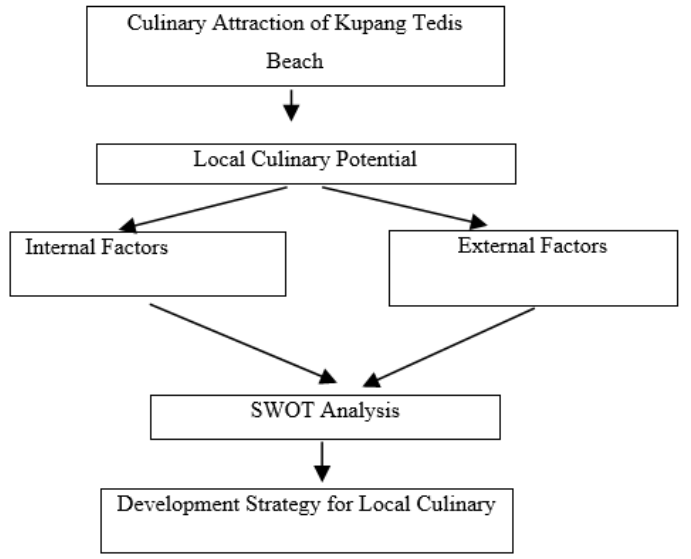

Fig. 1. Thinking scheme of the research study.

\section{METHODS}

The approach used in this research is descriptive qualitative with the research location of Tedis Beach, Kupang. The type of data used in this research is qualitative data in descriptive form [15]. The data sources used are primary data obtained from observations and interviews. Data collection was carried out through direct observation by observing tourism activities related to local culinary around Tedis beach. Data collection was also carried out by interviewing several culinary figures, especially culinary tourism actors in the research location Secondary data sources consist of documents and scientific journals. Furthermore, the data is analysed in several stages, namely data reduction, display data and conclusion, which are then studied using theory and concepts [16]. The results of the data analysis were processed through data grouping after which strategy was formulated.

The compilation of external and internal strategic factors is made in the SWOT matrix. The SWOT matrix clearly describes how the opportunities and external threats faced can be adjusted according to their strengths and weaknesses. This matrix produces four alternative strategies, namely SO, ST, 
WO, and WT [17]. Then the results of the SWOT analysis are used to plan local culinary development strategies with the aim of increasing the tourist attraction of Tedis Beach

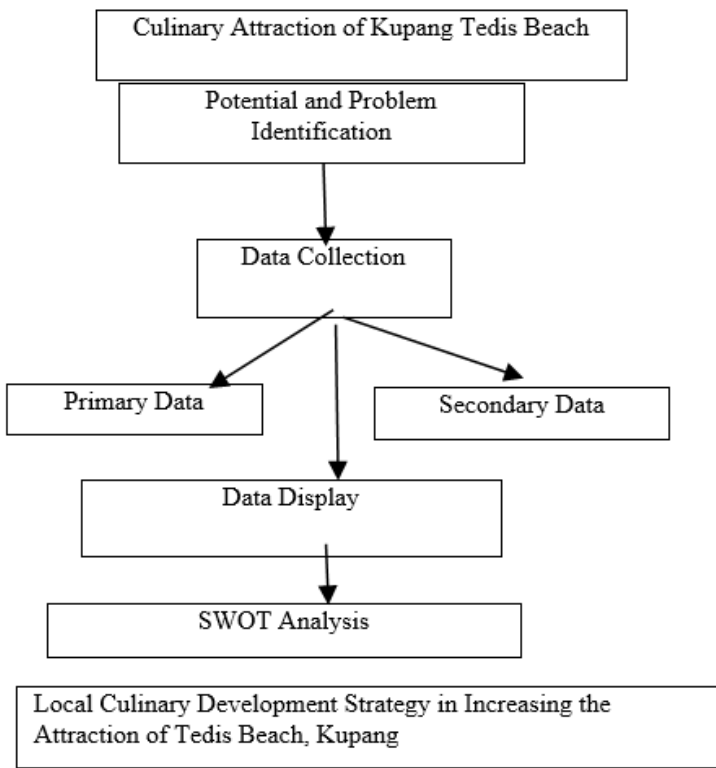

Fig. 2. Research procedure diagram.

\section{RESULT AND DISCUSSION}

Kupang City is one of the well-known culinary tourism destinations in East Nusa Tenggara Province. Very diverse local cuisine makes Kupang City especially Tedis Beach very rich in culinary tourism potential that can be used as one of the tourist attractions in addition to the natural scenery around Tedis Beach. The most positively perceived dimension is the cultural experience and then it is seen that respectively variety and table manners, food taste, restaurant service, health and hygiene are listed. In other words, local foods are an important part of the culture of a destination. For this reason, local foods provide a better understanding of the local culture [18]. Its location near the beach makes it also a source of processed food that is dominated by seafood. Some types of local culinary can be a tourism potential, namely;

\section{A. Bose Corn}

Bose corn is one of the local foods that are the mainstay of the people of East Nusa Tenggara in general. Carbohydrate sources are usually obtained from rice in several provinces in Indonesia, but in the city of Kupang the people more often consume corn so that a lot of local culinary in NTT is sourced from corn.

The process of making bose corn, corn is crushed using mortar, pounded corn until the skin is removed and cleaned, after that the corn is roasted. then boiled together with sugar and salt, in this dish usually mixed with red beans and peanuts in it. The savoury that is on this porridge, because this dish also contains coconut milk.

\section{B. Fish Lawar}

The position of the city of Kupang, which is close to the ocean, especially Tedis Beach, makes fish-based dishes dominate, one of that dishes is Fish Lawar. Fish Lawar is a type of local culinary that does not use the process of cooking alias raw. Fishar Lawar is made from thinly cut marine fish and cleaned and then soaked in a mixture of vinegar, lime and added salt. Usually, the fish used in this lawar are anchovies. Fish Lawar is usually accompanied by Bose corn as a complement to this local culinary.

\section{Tamarind Fish}

As a maritime country, Indonesian territory does have high marine income potential, especially fish. Because of the large potential of these fisheries, various types of processed fish are also known in various regions. Kupang has several special culinary, one of which is sour fish.

Almost every area that is close to the sea or other freshwater waters has its own type of processed fish. There are used as snacks, complementary foods such as crackers, and cooked directly with a variety of specialties and flavours.

The typical kupang tamarind fish usually uses fish known by the local community as samge fish, but can also be replaced with tuna, bander grouper, and catfish. The sour taste that becomes an interesting flavour of this dish is also produced from the use of starfruit. The spices used are even simpler without using coriander. So that the basic flavour of the broth is not too heavy so the sour taste becomes very delicious on the tongue.

Although the spices used are very simple, such as turmeric, ginger, orange leaves, onions, lemongrass, galangal and leeks, but it can ward off the fishy smell of the fish.

\section{Ruтри Rampe}

Rumpu rampe is one of the well-known local culinary preparations in Kupang City Papaya flowers are known for their bitter taste. Nevertheless, it turns out that many people also process it into delicious dishes without bitter taste. It teaches that there is always something good that we can get from every problem of life that we experience, even though what we experience is something bad. This is then held by the people of NTT from time to time. The philosophy can be logically translated through the taste of this cuisine. Through the cooking process, the bitter taste of papaya flowers can indeed be changed to be more savoury. For example, such as processed papaya flowers called rumpu rampe, which became a special meal for the people of NTT. Rumpu rampe not only contains papaya flowers, this savoury and slightly spicy dish is also mixed with cassava leaves, banana heart and smoked fish.

How to make it requires papaya flowers, the banana heart that has been thinly sliced and cassava leaves. Boil all ingredients until soft. Boiling papaya flowers together with cassava leaves is one way to reduce the bitter taste. This method is also effective for processing papaya leaves mixed 
with various herbs, namely salt, onion, garlic, red cayenne, tomato and shrimp paste. How to process this dish stir-fry the spices that have been ground until fragrant. Afterward, add papaya flowers, cassava leaves and papaya heart. Add smoked fish or anchovies to taste. Cook until the vegetables are withered.

\section{E. Various Sea Preparations}

Due to the abundant water resources, culinary along Tedis Beach is dominated by processed seafood processed either with fat/oil media or using direct fire media or burned accompanied by several chili variants as a compliment. Examples of some of the culinary include: fried squid in Padang sauce, spicy shrimp sauce, grilled fish sauce dabu-dabu, grilled fish sauce soy sauce and also various other sea preparations

\section{F. Various Indonesian Cuisine}

In addition to the typical menu of Kupang City, several culinary potentials from various regions are also offered in several food outlets around Tedis Beach. Some food stalls offer other popular culinary including fried rice, satay, meatballs, and fresh vegetables.

The diversity that is sold at food outlets adds to the choices for tourists who visit so that many local culinary unconsciously exposed to tourism activities. In addition to heavy food, several types of snacks are served at outlets that sell around the beach, namely; roasted corn, boiled corn, and spicy roasted banana

The variety of local culinary potentials requires several appropriate strategies to produce attractive tourism product packages for tourists. The resulting tourism product packaging is also expected to not only be limited to the consumer product side but it involves activities and emphasizes the experiences generated from tourism activities. Referring to this, the potential of existing local culinary needs to be developed further so that it can be known and become an attraction for tourists. To get the right strategy, it is necessary to study the factors that influence it, among others. In this report, local dishes, which have become an essential element for understanding the culture, traditions and intangible heritage of destination are considered as a reflection of destination and local people [19]. Therefore, local foods are both an ideal product as attraction element for destinations and also a useful marketing tool [20].

1) Internal factors: Internal factors that influence the development of local culinary potential in Tedis Beach are internal factors consisting of strengths and weaknesses themselves. Strengths that are owned in terms of characteristics and authenticity include a unique variety of culinary culture, both in taste, as well as how to process and serve it, fresh food raw materials, especially types of food made from marine animals, as well as the diversity of local culinary types. most of them have local culinary cooking skills, there are cultures related to local culinary, one of which is simple and unique cooking methods. While the weakness is the weak ability of the community to create representative culinary tourism packages. Most of the food entrepreneurs around the coast of Tedis lack local specialties as the main products. The ability and creativity of culinary businesses is still low.

2) External factors: External factors that influence the development of local culinary in Tedis beach are those from outside which consist of threats and opportunities that arise and must be faced. Opportunities started with Tedis beach have beautiful views that make tourists interested in tasting local cuisine while enjoying the fresh air and beautiful beach views, the cost of local culinary production is very affordable because natural resources on Tedis Beach are abundant, food ingredients are easy to obtain and access the road to Tedis Beach is quite adequate while the threats that must be faced include; competition between one outlet with local culinary outlets offering the same products, the growth of food outlets that sell international culinary foods where tourists come from and the development of ways of processing food that was previously traditionally processed shifted to modern ways because it was considered easier.

TABLE I.

SWOT MATRIX

\begin{tabular}{|l|l|l|}
\hline $\begin{array}{l}\text { Internal } \\
\text { Factors }\end{array}$ & $\begin{array}{l}\text { Strength: } \\
\text { 1. Typical food that has its own taste } \\
\text { 2. Fresh food ingredients } \\
\text { 3. Types of diverse local cuisine } \\
\text { 4. The uniqueness and authenticity in processing and } \\
\text { serving local cuisine } \\
\begin{array}{l}\text { 5. Diversity of water resources around Tedis Beach } \\
\text { 6. Surrounding communities have skills in processing local } \\
\text { culinary }\end{array}\end{array}$ & $\begin{array}{l}\text { Weakness: } \\
\text { 1. Presentation of food is still simple } \\
\text { 2. Cleanliness of the location around local culinary sales outlets is less } \\
\text { 3ygienic } \\
\text { the food is served } \\
\text { 4. Type of local food is less varied still monotonous } \\
\text { 5. Lack of adequate facilities, one of which is toilet }\end{array}$ \\
\hline
\end{tabular}


Table I. Cont.

\begin{tabular}{|c|c|c|}
\hline \multicolumn{3}{|l|}{ ternal factors } \\
\hline Oppu & O Strategy (Strength Opportunities) & O Strategy ( Weakness Opportunities) \\
\hline $\begin{array}{l}\text { 1. Tedis Beach has beautiful scenery so that } \\
\text { it can support tourists who are interested in } \\
\text { coming to taste the local cuisine } \\
\text { 2. Affordable local culinary production costs } \\
\text { 3. Food ingredients that are easily obtained } \\
\text { and varied } \\
\text { 4. Tourist visits have increased } \\
\text { 5. Adequate road access }\end{array}$ & $\begin{array}{l}\text { Utilize all the power to create opportunities, } \\
\text { including: } \\
\text { 1. Preserve and further enhance the local culinary } \\
\text { culture } \\
\text { 2. Utilizing fresh raw materials and easy to obtain } \\
\text { 3. Types of diverse local culinary by utilizing raw } \\
\text { materials that are easily obtained } \\
\text { 4. the uniqueness and authenticity of how to } \\
\text { process local culinary can fill tourist visits in } \\
\text { conducting tourism activities }\end{array}$ & $\begin{array}{l}\text { Overcoming the weaknesses in using opportunities } \\
\text { namely; } \\
\text { 1. Improve the presentation or appearance of dishes } \\
\text { to support the beach's natural scenery } \\
2 \text {. Be aware of the cleanliness of food sales } \\
\text { locations } \\
\text { 3. more emphasis on food processing hygiene } \\
\text { 4. The types of local culinary offered are still } \\
\text { monotonous and must be protected by abundant and } \\
\text { diverse raw materials }\end{array}$ \\
\hline $\begin{array}{l}\text { Threats: } \\
\text { 1. Competition between outlets selling } \\
\text { similar types of local culinary } \\
\text { 2. The growth of food outlets that sell types } \\
\text { of international culinary food which is where } \\
\text { tourists come from } \\
\text { 3. The development of ways of food } \\
\text { processing that had been traditionally } \\
\text { processed shifted to modern ways }\end{array}$ & $\begin{array}{l}\text { Utilize the power to deal with threats, namely: } \\
\text { 1. utilize a variety of local culinary types to deal } \\
\text { with outlet competition } \\
\text { 2. utilizing fresh food ingredients that have their } \\
\text { own character } \\
\text { 3. utilizing diverse types of local culinary, coupled } \\
\text { with varied food ingredients }\end{array}$ & $\begin{array}{l}\text { WT Strategy (Weakness Threats) } \\
\text { Overcoming weaknesses in order to deal with } \\
\text { threats, including: } \\
\text { 1. improve the appearance of the dish while adding } \\
\text { variety } \\
\text { 2. improve location cleanliness, processing and } \\
\text { serving dishes } \\
\text { 3. increase traditional cooking knowledge in local } \\
\text { communities around the coast }\end{array}$ \\
\hline
\end{tabular}

Based on the matrix above, the development strategy can be described as follows:

\section{a) SO (Strength Opportunities) strategy:}

- Preserve and further enhance the local culinary culture by preserving the taste of cuisine so that it adds to the attraction of Tedis beach tourism that already has beautiful natural scenery

- Utilizing raw food ingredients that are fresh and easy to obtain so as to reduce the cost of food production

- Types of diverse local culinary by utilizing raw materials that are easily available make the community able to increase their ability to recreate other types of local culinary

- The uniqueness and authenticity of how to process local culinary can fill tourist visits in conducting tourism activities

b) WO (Weakness Opportunities) strategy: Overcoming the weaknesses in using opportunities namely:

- Improve the presentation or appearance of dishes to support the beach's natural scenery

- Be aware of the cleanliness of the sales location because tourists certainly see the conditions around the outlet, with affordable production costs, part of the budget allocation can be diverted to the cleaning budget

- Prioritize food processing hygiene because the dishes must not only taste good but must be clean and healthy looking at raw materials that are easily available, culinary entrepreneurs can utilize them
- The types of local culinary offered are still monotonous and must be protected by abundant and diverse raw materials

c) ST (Strength Threat) strategy: Harness the power to deal with threats, namely:

- utilize a variety of local culinary types to deal with outlet competition

- utilizing fresh food ingredients that have their own character coupled with unique ways of processing and serving so as to overcome the growth of international cuisine

- utilizing diverse types of local culinary, coupled with varied food raw materials and the ability of the community to process local culinary traditionally can be displayed so that tourists can see in order to be able to suppress the growth rate of food processing in a modern and international manner

d) WT (Weakness Threat) strategy: Overcoming weaknesses in order to deal with threats, including: Improve the appearance of dishes to be better and at the same time add variations both in processing and serving local cuisine, Improving location cleanliness, processing and serving dishes by providing direction / assistance in order to provide awareness of the importance of product hygiene and sanitation while providing understanding in maintaining traditional culinary culture, especially in food processing and increase traditional cooking knowledge in local communities around the coast in order to avoid using modern or international cooking methods. 


\section{CONCLUSION}

Culinary is one of the supporting aspects and is one of the motivations of tourists coming to visit Tedis Beach. From the discussion of some of the strategies that have been described, it seems clear that local culinary has its advantages, namely uniqueness that cannot be obtained in other regions plus a beautiful view even though local culinary entrepreneurs around Tedis Beach pay less attention to appearance, both food appearance, outlets, and personal. Incessant types of international cuisine that enter through the franchise around Tedis Beach can be used as momentum in further increasing the variety and distinctiveness of cuisine while maximizing tourist arrivals through Kupang both domestically and abroad

\section{REFERENCES}

[1] P. Bjork H. Kauppinen-Raisanen, "Destination foodscape: a stage for travelers food experience," Tourism Management, vol. 71, no. 1, pp. 466-475, 2016.

[2] K.H. Lee and N. Scott, "Food tourism reviewed using the paradigm funnel approach," Journal of Culinary Science \& Technology, vol. 13, no. 2, pp. 95-115, 2015.

[3] Y.C. Lin, T.E. Pearson and L.A. Cai, "Food as form of destination identity: A tourism destination brand perspective," Tourism and Hospitality Research, vol. 11, no. 1, pp. 30-48, 2011.

[4] P. Kotler, Marketing Management. Jakarta: Erlangga, 2018.

[5] S. Sedarmayanti, Strategy Management. Bandung: Refika Aditama, 2014.

[6] R. Reid and D. Bojanic, Hospitality Marketing Management 4th Edition.Wiley, 2006.

[7] S. Suwena and W. Widyatmaja, Basic Knowledge of Tourism. Denpasar: Udayana University Press, 2010.

[8] H. Hermawan, "The Influence of Tourist Attraction, Safety and Tourism Facilities on Satisfaction and Its Impact on Tourist Loyalty: Study of
Community Based Tourism at Nglanggeran Purba Volcano," Means of Tourism Information: Media Tour, vol. 15, no. 1, pp. 562-577, 2017.

[9] I. Ismayanti, Introduction to Tourism. Jakarta: Grasindo, 2010.

[10] E. Emayanti, Encyclopaedia of Traditional Food in Java and Madura Islands, 2003.

[11] Z. Pienak, W. Verbeke, F. Vanhonacker, L. Guerrero and M. Hersleth, "Association between Traditional Food Consumption and Motives for Food Choice in Six European Countries," Appetite Journal, vol. 53, pp. 101-108, 2009.

[12] J.R. Ritchie and G.I. Crouch, "A model of destination competitiveness/sustainability: Brazilian perspectives," Revista de Administracao Publicia, vol. 44, no. 5, pp. 1049-1066, 2010.

[13] B. Okumus and G. Cetin, "Marketing Istanbul as a culinary destination," Journal of Destination Marketing \& Management, vol. 9, pp. 340-346, 2018.

[14] Y.C. Lin, T.E. Pearson and L.A. Cai, "Food as form of destination identity: A tourism destination brand perspective," Tourism and Hospitality Research, vol. 11, no. 1, pp. 30-48, 2011.

[15] S. Sugiyono, Quantitative Research Methods, Qualitative and R \& D. Bandung: Alfabeta, 2016.

[16] J. Creswell, Qualitative, Quantitative, and Mixed Methods Approaches. Yogyakarta: Student Library, 2014.

[17] F. Rangkuti, Techniques for Dissecting Business Cases SWOT Analysis How to Calculate Weight, Rating, and OCAI. Jakarta: Publisher PT. Gramedia Pustaka Utama, 2013.

[18] J.C.P. Galvez, M.J. Granda, T. Lopez-Guzman and J.R. Coronel, "Local gastronomy, culture and tourism sustainable cities: The behavior of the American tourist," Sustainable Cities and Society, vol. 32, pp. 604-612, 2017.

[19] P. Bjork and H. Kauppinen-Raisanen, "Destination foodscape;A stage for travelers food experience," Tourism Management, vol. 71, no. 1, pp. 466-475, 2019.

[20] G.E. Du Rand and E. Heath, "Towards a framework for food tourism as an element of destination marketing," Current Issues in Tourism, vol. 9, no. 3, pp. 206-234, 2006. 